\title{
INCREASING THE EFFICIENCY OF DATA GATHERING IN CLUSTERED WIRELESS SENSOR NETWORKS USING UAV
}

\author{
${ }^{1}$ Valery A. Romaniuk, ${ }^{2}$ Olexandr I. Lysenko, ${ }^{2}$ Anton V. Romaniuk, ${ }^{1}$ Olexandr V. Zhuk \\ ${ }^{1}$ Military Institute of Telecommunications and Informatization, Kyiv, Ukraine \\ ${ }^{2}$ Igor Sikorsky Kyiv Politechnic Institute, Kyiv, Ukraine
}

Background. To implement the process of collecting UAV monitoring data from sensor nodes in the wireless sensor networks (WSN) control system, it is necessary to implement appropriate methods and algorithms. To increase the efficiency of the data collection process in the WSN, it is clustered, the main cluster nodes are selected that collect monitoring data in the cluster and transmit this data to the UAV when it approaches. The methods proposed today for collecting data from nodes of sensor networks using UAVs do not consider the requirements of various target control functions, especially the functioning of specific networks and require further improvement.

Objective. The aim of the work is to analyze and consider ways to improve the efficiency of the process of collecting data from sensor nodes of the WSN using UAVs during its clustering.

Methods. In contrast to the traditional ways to solve the problem of collecting UAV monitoring data from WSN nodes, a set of methods is proposed to achieve various objective control functions (maximizing WSN functioning time, minimizing data collection time, minimizing the number of UAVs) at various stages of network operation.

Results. The application of the proposed methods to increase the efficiency of monitoring data collection allows increasing the network lifetime, reducing data collection time and reducing the number of UAVs required for data collection.

Conclusions. To achieve various target management functions at the main stages of monitoring data collection in wireless sensor networks, many methods have been proposed to improve the basic indicators of their functioning.

Keywords: wireless sensor networks; clustering; collection of monitoring data from UAVs; efficiency.

\section{Introduction}

Modern wireless sensor network (WSN) technologies are becoming popular in various applications (observation of forest areas, fields, oil and gas pipelines, borders, battlefield, environmental and meteorological monitoring, search and rescue missions, etc.), including in remote (inaccessible) areas where there is no telecommunication infrastructure [1]. WSN can be designed to operate for several months or even years in hard-to-reach areas. For data collection in such conditions it is proposed to use the UAVs [1].

The autonomous sensor nodes monitor certain parameters of their coverage areas, store the received data and wait for their transfer to the data collection center via UAV when it appears in the radio communication zone. UAVs fly over the area of interest and collect monitoring data from sensor nodes. When flying over the territory along a certain route, the UAV establishes a radio link with the sensor nodes, receives monitoring data from them, stores them and on their return transmits them to the data collection center for further analysis. A feature of this class of networks is the limited resources of its nodes by: battery power, processor performance, memory, transmitter power, radio bandwidth, etc.
Modern WSNs can consist of hundreds or even thousands of sensory nodes. Replacing batteries for so many nodes may be impractical or even impossible. Reducing (redistributing) energy consumption by sensory nodes is therefore critical to increasing their operating time. One of the ways to solve this problem is the clustering of the network, which allows reducing the length of the flight route and increasing the time of WSN functioning.

The methods of data collection from the nodes of sensor networks with the use of UAVs proposed today do not consider the requirements of various target control functions [2 - 4], the peculiarities of functioning of specific networks and require further improvement. The purpose of the work is to analyze and consider ways to improve the efficiency of the process of data collection from sensor nodes of the WSN using UAVs in its clustering.

\section{Statement of objective}

The methods of collecting monitoring data from sensor nodes to the UAV can be divided into two main groups.

1). Direct collection of monitoring data from the UAV from each node. 
In this case the UAV flies over the sensor field along the calculated route and collects data from each sensor node that stores the monitoring data of its area. The main advantage of this method is the simplicity of the algorithms of functioning of the network nodes (if there is a connection with the UAV, the node must transmit monitoring data to it). The disadvantage is a significant increase in the UAV flight time, higher requirements to the UAV parameters, and, accordingly, a significant increase in the time of collecting monitoring information.

2) Collecting the UAV information from the selected (head) nodes that store information about the monitoring parameters of the nodes of its network cluster.

In this method, according to a certain algorithm, the network is divided into clusters, which select the head nodes of clusters [2 - 6]. Each cluster is built its topology and routes of data transmission from nodesmonitoring to the main nodes that collect data from the nodes of its network cluster to the UAV flight. Next, the UAV (or network control center) calculates the route to fly only the main nodes, the UAV flies and collects information from them. The disadvantages of this method - it is necessary to synthesize and implement additional algorithms of network management [3 - 6]: dividing the network into clusters, the choice of the main nodes in the clusters, building the topology of the cluster, the organization of the routing process of data collection to the main nodes, calculating the flight path of the UAV of the main nodes, etc. Advantage: the use of the main nodes will reduce energy consumption of the cluster nodes, reduce flight time and thus reduce the time of collecting monitoring information.

Target control functions during data collection can be $[5-6]$ :

1. Maximize or ensure the specified operating time of the WSN $\left(\max T_{\mathrm{f}}\right.$ or $\left.T_{\mathrm{f}} \geq T_{\text {fgiv }}\right)$ with the specified limitations on the time $T_{\text {col }}$ and volume of $V_{\mathrm{md}}$ of the collected monitoring data, the number of available UAVs for use $-N_{\text {giv }}$.

This target function is achieved by reducing the energy consumption of the WSN nodes in the following ways (Fig. 1):

reducing the transmission power between two sensor nodes;

reducing the distance and, consequently, reducing the transmission power and energy consumption between the cluster and UAV head units, which allows to increase the data transmission speed (for example, for the IEEE 802.11 protocol);

redistribution of energy consumption between nodes through the implementation of appropriate network management algorithms - coverage algorithms (dividing into independent coverage nodes and making monitoring schedules by sets), algorithms for building and maintaining the topology and data transmission routes in clusters [7], algorithms for selecting the main nodes in the cluster (through the use of energydependent metrics);

reducing the volume of service traffic in the implementation of management algorithms at all OSI levels (for example, by introducing cross-level);

reducing the computational complexity of network management algorithms.

\begin{tabular}{|c|c|c|}
\hline \multicolumn{3}{|c|}{ Ways to improve the efficiency of UAV data collection while clustering WSN } \\
\hline $\begin{array}{l}\text { Target } \\
\text { functions }\end{array}$ & $\begin{array}{l}\text { In terms of the stages of } \\
\text { WSN functioning }\end{array}$ & Methods of implementation \\
\hline $\begin{array}{l}\max T_{\mathrm{f}} \\
-\min T_{\mathrm{col}} \\
\min N\end{array}$ & $\begin{array}{l}\text { - clustering } \\
\text { - cluster size and quantity } \\
\text { - cluster topology design } \\
\text { route construction } \\
\text { - monitoring data transmission } \\
\text { - calculation of flying points } \\
\text { - flight route calculation } \\
\text { rotation of the main nodes }\end{array}$ & $\begin{array}{l}\text { - cluster size and quantity optimization } \\
\text { - reduction of node transmission power } \\
\text { - reduction the distance between the UAV and the node } \\
\text { - redistribution of energy consumption between nodes } \\
\text { - service traffic reduction } \\
\text { - algorithm complexity reduction } \\
\text { - node sleep time increasing } \\
\text { - decrease in flyby points (virtual clustering) } \\
\text { UAV coverage area max bandwidth }\end{array}$ \\
\hline
\end{tabular}

Fig. 1. Ways to improve the efficiency of monitoring data collection 
In addition, the reduction of power consumption by sensor nodes in the cluster can be achieved by means of:

reducing the time nodes stay in active state or increasing sleep mode;

reducing the monitoring radius of the node or the area $\neg$ monitoring by the network (formation of $\alpha$ coverage);

creating an excessive number of nodes required to cover a given area (object);

aggregation of transmitted monitoring data from simple nodes to the main one.

2. Minimize or ensure the specified data collection time (min $T_{\text {col }}$ or $T_{\text {col }} \leq T_{\text {colgiv }}$ ) with a set limit on the number of UAV $N \leq N_{\text {giv }}$, he specified amount of monitoring data $V_{\text {md }} \leq V_{\text {mdgiv }}$ and the operating time of the $T_{\mathrm{f}} \leq T_{\text {fivi }}[5-6]$.

The time of data collection depends on the length of the flight route (depends on the number of clusters, the location of their main nodes, the designated points of exchange with the UAV), the speed of the UAV flight, the speed of data exchange between the main nodes and the UAV (depending, among other things, on the distance between them), and others.

3. Minimize the number of UAVs $(\min N)$, required to collect data with the specified quality, with restrictions on the time of data collection $T_{\text {col }} \leq T_{\text {colgiv }}$, and the time of operation of the network $T_{\mathrm{f}} \leq T_{\text {fgiv }}$.

It is achieved by dividing WSN into subnetworks and optimizing the process of data collection in each subnetwork.

\section{Implementation of objective management functions}

The presence of several target control functions leads to the tasks of multi-criteria optimization. In general, its solution will depend on the requirements set for the network management system. In a particular case the task of multi-criteria optimization can be solved by methods: main index, additive or multiplicative convolution, concessions, etc.

Realization of target functions of WSN management should be achieved at different stages of the network functioning (Fig. 1).

1. Network clustering is a key task to achieve minimization of node energy costs and network stability. There are a number of clustering algorithms, aimed at improving the performance of WSN [2 - 6]: reducing energy consumption of nodes, load balancing, increasing connectivity, reducing data transmission delay, optimizing the number of clusters, etc.

The process of building clusters includes the following stages: a) Calculating the number, size of clusters and rotation period of the main nodes. Optimization of these parameters should ensure the implementation of target management functions. Their specific values are determined by the WSN dimension, the area of the monitoring zone, the characteristics of sensor nodes (initial battery energy, energy consumption for monitoring, data reception and transmission, monitoring and transmission radii, exchange protocols, etc.) and UAV (flight time, energy reserve, flight altitude, speed of information exchange, etc.), adopted control algorithms and requirements for the process of data collection (maximum time of data collection, given amount of data, given network life, etc.).

Smaller number of clusters leads to a smaller number of main nodes, shorter UAV flight route length and reduces the flight time (data collection). However, it increases the diameter of clusters and, accordingly, increases the time for their organization. In addition, it increases the energy consumption of nodes for service traffic, data transmission from simple nodes to the main nodes is carried out on longer routes. To calculate the operating time of the WSN, we propose an analytical model that considers the energy consumption of nodes depending on its functions (only monitoring, monitoring plus routing, monitoring plus the main node of the cluster) and the amount of monitoring data, on the given time of network operation (or the number of rounds of data collection UAV) [5].

b) Formation of clusters [2 - 6]. It is carried out by exchanging service messages between the nodes with the implementation of appropriate algorithms for selecting the main nodes of clusters, considering the priority of the target functions of network management. The algorithm for selecting the main node should consider the convolution of the metrics: battery energy of the cluster node, the signal level in the radio channel node UAV, the location in the cluster (center or on the edges), etc.

c) Construction of the cluster topology [7]. It should be carried out according to the specified target network management functions (for example, to minimize energy consumption of nodes - the construction of energy efficient topology, minimizing transmission time - the construction of a small diameter topology, etc.).

d) Construction and support of routes in the cluster from simple nodes to the main ones by convolution of metrics that also consider the target control functions: transmission power, energy of nodes' batteries, throughput, etc. [8, 9]. 
2. Transfer of data to monitoring in clusters from simple nodes to the main nodes with specified quality on previously defined routes.

3 Finding the position in the UAV space (monitoring data collection points, in the simplest case the main node is the collection point).

In order to minimize the collection time, the minimum number of points (UAV positions) of data collection is searched. For this purpose, a virtual clustering of the head nodes is carried out, for example, using an algorithm FOREL (FORmal ELement) [10] with adaptation of the size of the UAV coverage area $R$ (to reduce the distance between the main nodes and the UAV) Fig. 2.

To maximize the throughput between the main nodes of clusters and the UAV in its coverage area it is proposed to calculate its position depending on their load, using the appropriate mathematical model [11].

4. Construction of routes considering various target functions for overflight of collection points: the shortest (target function - minimum time of data collection); routes with overflight of critical nodes (according to the availability of battery energy, data volume, efficiency of information), etc. $[6,7,11]$.

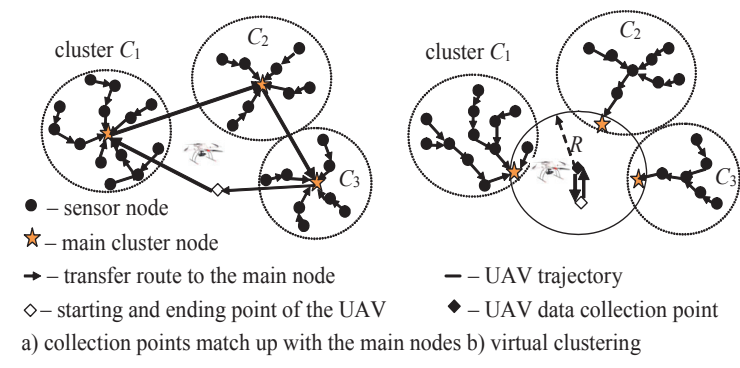

Fig. 2. UAV flight options for different locations of data collection points

5. UAV flight along the calculated route and data collection. For this purpose, the altitude (the distance between the UAV and the main node is set to ensure a given data transmission speed) and the flight speed are calculated to ensure sufficient time to ensure the quality of all monitoring data transmission [6, 11]. The transmission power level between the UAV and the main unit is kept to a minimum.

6. Rotation of main cluster nodes. Clusters are restructured: exchange of service information and selection of new main cluster nodes, construction of new cluster topology, routes of transfer from monitoring nodes to the main nodes. Calculation of collection points and routes of UAV flight. Selection of new main cluster nodes should be performed depending on the target management functions set by the network control center.

The modeling of the proposed network management methods shows the effectiveness of their implementation. For WSN of 100, 150, 200 nodes the increase in time of network operation was up to $20 \%$, reduction of time of data collection - up to $50 \%$.

\section{CONCLUSION}

A set of methods for managing the process of collecting monitoring data from the nodes of the WSN using the UAV is proposed, which allows to implement various target functions of network management: minimizing network life time, reducing data collection time, minimizing the number of UAVs. The application of specific methods of data collection management will be determined by the characteristics of the network, network nodes and the UAV, as well as requirements for the quality of data collection. The proposed methods can be used in a special software system of data collection management in FSU using the UAV.

\section{REFERENCES}

[1] Imad Jawhar, Nader Mohamed, Jameela Al-Jarood. UAV-based data communication in wireless sensor networks: Models and Strategies. International Conference on Unmanned Aircraft Systems (ICUAS), 2015.

[2] Huseyin Okcu, Mujdat Soyturk. Distributed Clustering Approach for UAV Integrated Wireless Sensor Networks. International Journal of Ad Hoc and Ubiquitous Computing, 2014, Vol.15, No. 1-3, pages: $106-120$.

[3] Asim Zeb, A. K. M. Muzahidul Islam, Mahdi Zareei, Ishtiak Mamoon, Nafees Mansoor, Sabariah Baharun, Yoshiaki Katayama, Shozo Komaki. Clustering Analysis in Wireless Sensor Networks: The Ambit of Performance Metrics and Schemes Taxonomy. International Journal of Distributed Sensor Networks. 2016.

[4] Tony Ducrocq, Michaël Hauspie, Nathalie Mitton. Balancing Energy Consumption in Clustered Wireless Sensor Networks ISRN Sensor Networks Volume 2013, 14 pages, http://dx.doi.org/10.1155/2013/314732.

[5] Romaniuk A. The UAV monitoring data collection management tasks in wireless sensor networks. Collection of scientific papers MITI. Kyiv. 2018. № 2. pp. $103-112$.

[6] Romaniuk A. Method of the date collecting in wireless sensor networks with unmanned aerial vehicles. Collection of scientific papers MITI. Kyiv. 2018. № 1. pp. 90 - 99. 
[7] Zhuk A., Romaniuk A., Tkachenko D. Analyze topology control methods wireless sensor networks. Collection of scientific papers MITI. Kyiv. 2017. № 2. pp. $41-47$.

[8] Amit Sarkar, T.Senthil Murugan. Routing protocols for wireless sensor networks: What the literature says? Alexandria Engineering Journal. Volume 55, Issue 4, December 2016, Pages 3173-3183. https://doi.org/10.1016/j.aej.2016.08.003.

[9] Romaniuk V., Zhuk O., Tkachenko D. Power management in wireless sensor networks. Bulletin of NTU "KhPI". Series: Mechanical-technological systems and complexes. Kharkov: NTU "KhPI", 2017. № 20 (1242). pp. 53 - 59.
[10] Zagorujko N. G. Prikladnye metody analiza dannyh i znanij. Novosibirsk: IM SO RAN, 1999. $270 \mathrm{~s}$.

[11] Safwan Alfattani, Wael Jaafar, Halim Yanikomeroglu, Abbas Yongacoglu. Multi-UAV Data Collection Framework for Wireless Sensor Networks. 2019 IEEE Global Communications Conference https://arxiv.org/pdf/1910.10792.pdf.

[12] Stepanenko E. Positioning model of telecommunication aeroplatform to optimize the capacity of nodes in its coverage area. Collection of scientific papers MITI. Kyiv. 2019. № 1. pp. 97 104.

Лисенко А.І., Романюк В.А., Романюк А.В, Жук О.В.

Підвищення ефективності збору даних моніторингу БПЛА при кластеризації бездротових сенсорних мереж

Проблематика. Для реалізації процесу збору даних моніторингу БпЛА від сенсорних вузлів в системі управління беспроводовими сенсорними мережами (БСМ) необхідно реалізувати відповідні методи і алгоритми. Для підвищення ефективності процесу збору даних в БСМ проводиться її кластеризація, виділяються головні вузли кластерів, що збирають дані моніторингу в кластері і передають ці дані на БпЛА при його підльоті. Запропоновані на сьогодні методи збору даних з вузлів сенсорних мереж з використанням БпЛА не враховують вимоги різних цільових функцій управління, особливості функціонування конкретних мереж і вимагають подальшого вдосконалення.

Мета досліджень. Метою роботи є аналіз і розгляд способів підвищення ефективності процесу збору даних 3 сенсорних вузлів БСМ з використанням БпЛА при ії кластеризації.

Методика реалізації. На відміну від традиційних шляхів вирішення проблеми збору даних моніторингу БпЛА від вузлів БСМ запропонована сукупність методів досягнення різних цільових функцій управління (максимізація часу функціонування БСМ, мінімізація часу збору даних, мінімізація кількості БпЛА) на різних етапах функціонування мережі: кластеризація мережі; передача даних моніторингу в кластерах від простих вузлів до головних вузлів; знаходження положення в просторі БпЛА; побудова маршруту обльоту точок збору; політ БпЛА за розрахованим маршрутом і збір даних, ротація головних вузлів кластерів.

Результати досліджень. Застосування запропонованих методів підвищення ефективності збору даних моніторингу дозволяє збільшити час життя мережі, зменшити час збору даних і зменшити кількість БпЛА, необхідних для збору даних.

Висновки. Для досягнення різних цільових функцій управління на основних етапах збору даних моніторингу в бездротових сенсорних мережах запропоновано безліч методів, що дозволяють поліпшити основні показники їх функціонування.

Ключові слова: бездротові сенсорні мережі; кластеризація; збір даних моніторингу з БпЛА; ефективність.

Лысенко А.И., Романюк В.А., Романюк А.В, Жук А.В.

Повышение эффективности сбора данных мониторинга БпЛА при кластеризации беспроводных сенсорных сетей

Проблематика. Для реализации процесса сбора данных мониторинга БпЛА от сенсорных узлов в системе управления беспроводными сенсорными сетями (БСС) необходимо реализовать соответствующие методы и алгоритмы. Для повышения эффективности процесса сбора данных в БСС проводится ее кластеризация, выделяются главные узлы кластеров, собирающие данные мониторинга в кластере и передающие эти данные на БпЛА при его подлете. Предложенные на сегодня методы сбора данных с узлов сенсорных сетей с использованием БпЛА не учитывают требования различных целевых функций управления, особенности функционирования конкретных сетей и требуют дальнейшего совершенствования.

Цель исследований. Целью работы является анализ и рассмотрение способов повышения эффективности процесса сбора данных с сенсорных узлов БСС с использованием БпЛА при ее кластеризации. 
Методика реализации. В отличие от традиционных путей решения проблемы сбора данных мониторинга БпЛА от узлов БСС предложена совокупность методов достижения различных целевых функций управления (максимизация времени функционирования БСС, минимизация времени сбора данных, минимизация количества БпЛА) на различных этапах функционирования сети: кластеризация сети; передача данных мониторингу в кластерах от простых узлов к главным узлам; нахождение положения в пространстве БпЛА; построение маршрута облета точек сбора; полет БпЛА по рассчитанному маршруту и сбора данных, ротация главных узлов кластеров.

Результаты исследований. Применение предложенных методов повышения эффективности сбора данных мониторинга позволяет увеличить время жизни сети, уменьшить время сбора данных и уменьшить количество БпЛА, необходимых для сбора данных.

Выводы. Для достижения различных целевых функций управления на основных этапах сбора данных мониторинга в беспроводных сенсорных сетях предложено множество методов, позволяющих улучшить основные показатели их функционирования.

Ключевые слова: беспроводные сенсорные сети; кластеризация; сбор данных мониторинга 3 БПЛА; эффективность. 